\title{
Grass Carp: A Fish for Biological Management of Hydrilla and Other Aquatic Weeds in Florida ${ }^{1}$
}

\author{
David L. Sutton, Vernon V. Vandiver Jr., and Jeffrey E. Hill ${ }^{2}$
}

Abundant growth of aquatic plants causes serious problems in ponds, lakes, rivers, and irrigation and drainage throughout Florida. In some situations, native aquatic plants become weeds, but most often exotic plants introduced from areas outside the state flourish under the favorable growing conditions found in Florida. Long-term economical solutions to Florida's aquatic weed problems have been elusive and there is a need for control techniques to alleviate aquatic weed problems.

This bulletin provides information on a biological method, the grass carp (Ctenopharyngodon idella Val.), for management of some of Florida's aquatic weed problems. Emphasis is placed on use of this fish to control hydrilla (Hydrilla verticillata [L.f.] Royle) and other submersed aquatic plants.

Since the grass carp is a living organism, in contrast to either herbicides or mechanical devices used for aquatic weed management, a somewhat different approach is required. A knowledge of the life cycles of plants that become weeds and feeding behavior of the fish are important considerations in understanding the various ways in which grass carp can be used to manage plant problems. The grass carp will not be useful for all aquatic plant problems; rather it offers the potential to manage effectively and economically certain weeds.
Man has probably been the single most important factor in the spread of hydrilla (Figure 1) and other aquatic plants. The demand for aquatic plants used in aquariums and elsewhere has resulted in their sale and distribution throughout the country.

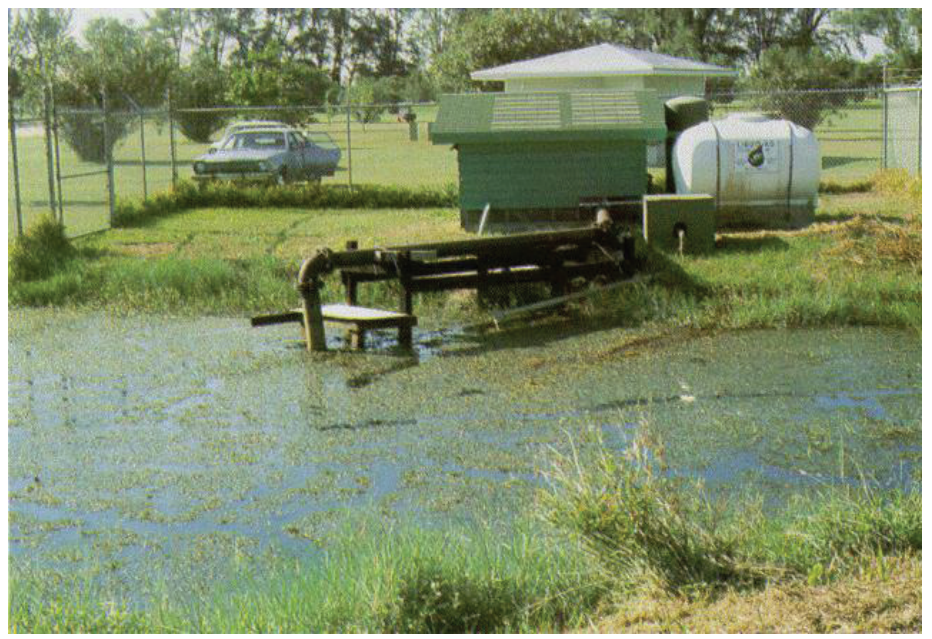

Figure 1. Dense Hydrilla growth can seriously impact agricultural operations, shown here blocking the intake line of an irrigation pump. Credits: David L. Sutton

Also, once established in natural waters, the plants may be spread by boaters traveling from one body of water to another. We hope that public recognition of problems some of these plants may cause will lead to regulations and public cooperation to cease their introduction and transportation, purposeful or inadvertent.

1. This document is Bulletin 867, Department of Fisheries and Aquacultural Sciences, Florida Cooperative Extension Service, Institute of Food and Agricultural Sciences, University of Florida. First published December 1986. Revised November 2012. Please visit the EDIS website at http://edis.ifas.ufl. edu.

2. David L. Sutton, professor (aquatic weeds), retired; Vernon V. Vandiver Jr., associate professor (aquatic weeds specialist), retired; and Jeffrey E. Hill, associate professor, School of Forest Resources and Conservation, Program in Fisheries and Aquatic Sciences, Tropical Aquaculture Laboratory, Ruskin, FL 33570.

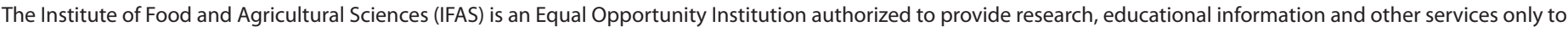

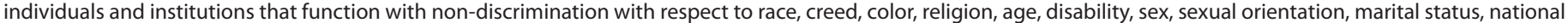
origin, political opinions or affiliations. U.S. Department of Agriculture, Cooperative Extension Service, University of Florida, IFAS, Florida A\&M University Cooperative Extension Program, and Boards of County Commissioners Cooperating. Thomas A. Obreza, Interim Dean 
Herbicides are frequently used for hydrilla control, but biological organisms offer unique advantages for management of hydrilla and other aquatic weeds. Advantages of using effective, safe organisms to manage aquatic weeds biologically include (1) longevity of the method once it has become established; (2) constant feeding activity against the growing weed; (3) low long-term costs; (4) high effectiveness on some plants; and (5) in the case of fish, the potential for conversion of the weed to a useful protein product (fish flesh).

The most promising biological agent for many submersed plant problems and some other aquatic weeds is the grass carp (Figure 2), also sometimes called the white amur.

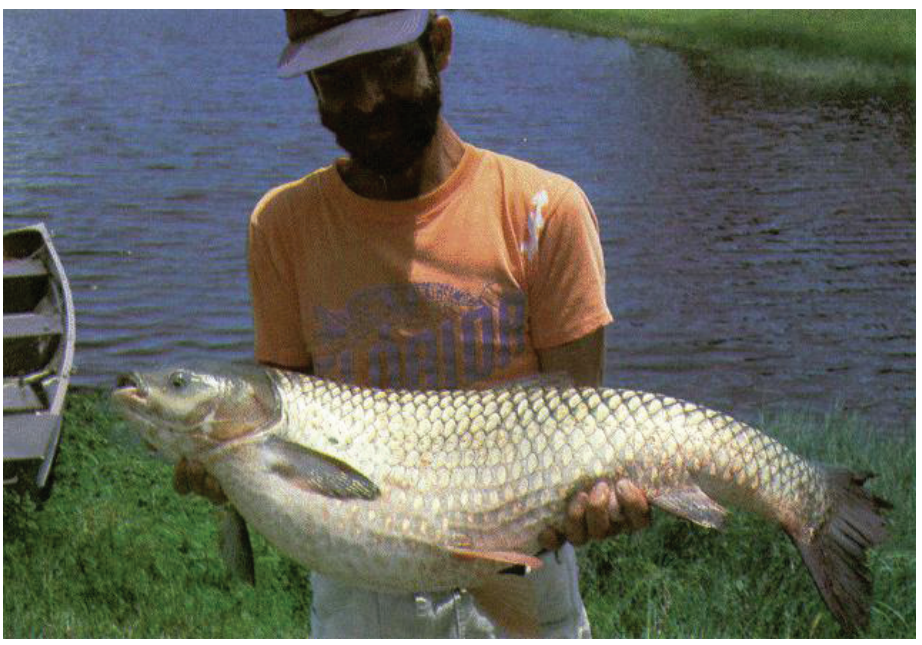

Figure 2. A mature grass carp, highly effective in controlling Hydrilla and many other noxious aquatic weeds.

Credits: David L. Sutton

\section{Description of Grass Carp}

This fish is indigenous to those rivers in the eastern part of the former Union of Soviet Socialist Republics (USSR) and China that flow into the Pacific Ocean between latitudes $50^{\circ}$ North and $23^{\circ}$ North.

The grass carp has been introduced into more than 50 countries throughout the world for aquatic weed control and aquaculture. In some countries, the grass carp is an integral part of fish culture and forms an important source of protein for human consumption.

The grass carp was considered for introduction into the U.S. primarily because of its plant-eating diet, which was thought to have great potential for the control of aquatic weeds. In 1963 the U.S. Bureau of Sport Fisheries and Wildlife Fish Farming Experiment Station, Stuttgart, Arkansas, in cooperation with Auburn University, imported grass carp for experimental purposes; in 1970, this fish was introduced into Florida primarily for researchers to study its ability to control hydrilla.

Wide-scale use of the grass carp in Florida and many other states during 1970 to 1984 was limited and closely regulated due to fears about its reproduction and negative impact on sport fish. Since the grass carp's potential for causing such problems was evident, early research focused on developing a fish that would be non-reproductive but would retain the grass carp's herbivorous diet.

The natural grass carp is diploid with a chromosome number $(2 \mathrm{~N})$ of 48 . During the 1980's, research with the grass carp resulted in the production of a sterile triploid grass carp (3N), which has an extra set of chromosomes. The aquatic weed control capabilities of the triploid fish are essentially the same as the diploid.

The triploid grass carp is produced in the same way as the diploid, except that fertilized eggs subjected to heat, cold, or pressure shock result in the formation of fish with an extra set of chromosomes for a total of 72 . The extra chromosomes make these fish sterile.

The nuclei of cells of the triploid grass carp are larger than those of diploid fish. An instrument such as the Coulter Counter can be used to measure the diameter of the nuclei of fish blood cells. Therefore, it is possible to screen fish considered for introduction into aquatic weed problem areas to assure that each fish stocked is a triploid.

The grass carp tolerates cold water and also flourishes and grows at rapid rates in warm waters such as those found in Florida. These herbivorous fish may grow at a rate of 2 pounds $(0.91 \mathrm{~kg})$ or more per month when sufficient vegetation is available. The young fish grow at a much faster rate than older, mature fish, and females grow faster than males. In Florida, some fish have grown to 40 pounds (18 $\mathrm{kg}$ ) with an apparent life span of approximately 10 years.

The grass carp is primarily a "grazer"; it tends to feed on the surface and in shallow water. At times it can be seen feeding with its back and tail extending above the surface.

The grass carp prefers submersed plants and the soft tips of young tender plants (Table 1). Small grass carp prefer musk-grass over hydrilla when both plants are present, but large fish will consume hydrilla before musk grass. Even though young fish will feed on various species of Cladophora and Spirogyra and other filamentous algae, the grass carp is not normally considered an effective method 
to control many types of algae. Feeding rates of large, mature fish on algae are not well known.

When the preferred food of the grass carp is not available, this fish feeds on terrestrial vegetation hanging over the surface of the water. In fact, the name "grass carp" comes from its unique ability to consume terrestrial grasses. Other terrestrial plants eaten by the grass carp range from banana leaves (Musa spp.) to various dried grasses, including clippings from golf courses or similar turf areas. Caution should be exercised when feeding grass clippings to grass carp. Some pesticides commonly used on turf areas are quite toxic to fish.

The ability of grass carp to consume and utilize aquatic plants depends on the size of both plants and fish. Additional factors which influence the feeding behavior of grass carp include their size, age, gender, and population density, and the species, abundance, and location of plants within a body of water.

\section{Management Techniques}

Birds, snakes, and other fish prey on small grass carp.

Based on measurements of mouth width and total length for largemouth bass (Micropterus salmoides Lacepede), it has been calculated that grass carp must be greater than 18 inches $(450 \mathrm{~mm})$ in length to eliminate predation. Therefore, when predators are present, fish to be stocked should be at least 12 inches $(0.3 \mathrm{~m})$ in length or 1 pound $(0.45 \mathrm{~kg})$ in weight for good survival. Mortality rates increase sharply with smaller fish.

Small grass carp have a better chance of survival if they are stocked when the weeds are dense enough to provide protective cover. When the weed biomass is low, such as after a herbicide treatment, use of mechanical methods, or in a new body of water, fish in good condition and weighing 5 pounds $(2.3 \mathrm{~kg})$ or more will survive better than smaller fish.

To remove hydrilla and other aquatic weeds with grass carp alone, fish must be stocked in sufficient numbers so that their consumption rate exceeds the growth rate of the plants. With so many factors influencing the feeding rate of the grass carp and the growth rate of the plants, it is impossible to give one specific stocking rate that will apply for every situation.

Rates of 20 to 255 grass carp per acre (50 to 638 fish per hectare) have been found to provide effective control of hydrilla.
Removal of hydrilla with 40 fish per acre (100 per ha) is shown in Figure 3 and Figure 4. A dense growth of any weed will obviously require more fish than a sparse amount of the plant. One approach is to stock 20 to 30 fish per acre (50 to 75 grass carp per hectare). Then in a year to a year and a half, add more fish if the desired level of control has not been achieved.

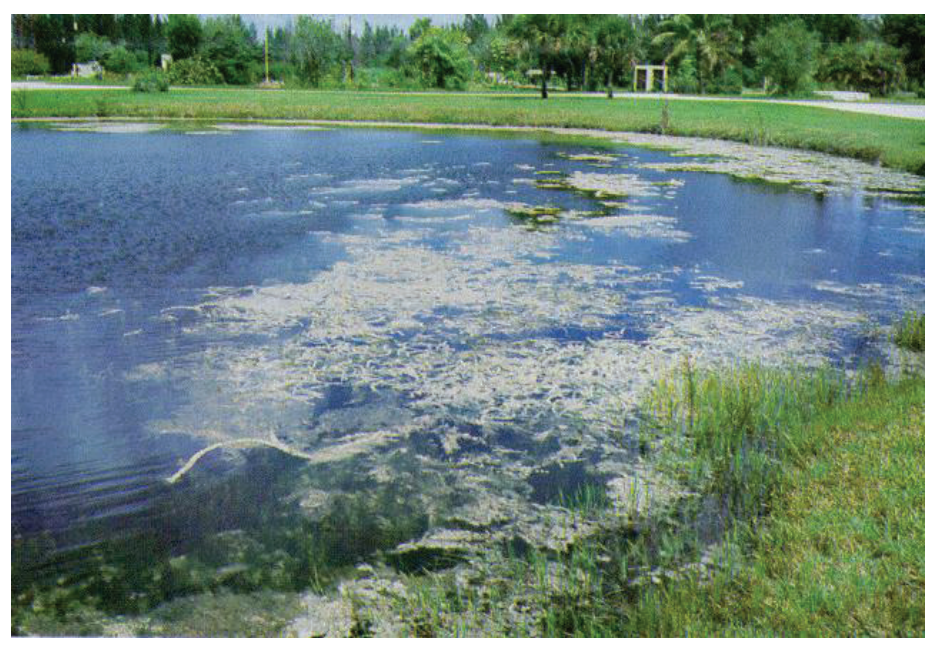

Figure 3. A heavy infestation of Hydrilla in a Southeast Florida pond. Credits: David L. Sutton

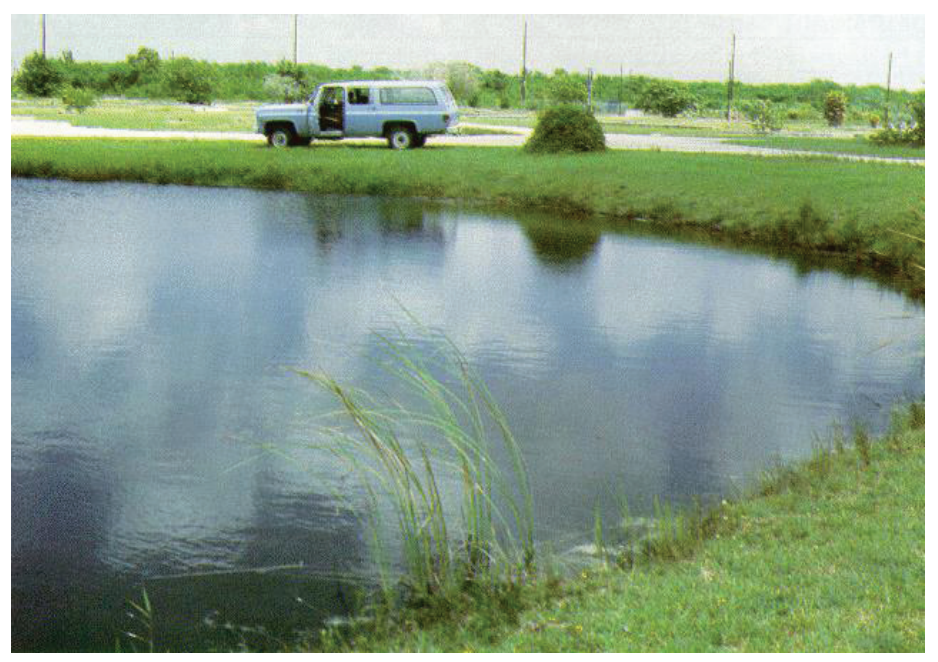

Figure 4. Pond (Shown in Figure 3) with Hydrilla controlled after one year following a stocking with forty grass carp per acre.

Credits: David L. Sutton

In a body of water, the area infested with weeds in relation to the total area may be taken into consideration when determining the number of fish to stock. Transect lines, a recording fathometer, biomass sampler, or aerial surveys can be used to help estimate the amount of weeds present. In this way, the fish can be stocked according to the amount of vegetation, rather than the total area of the body of water under consideration. 
Very low oxygen levels can be encountered during the early morning or on cloudy days in bodies of water containing dense weed growth. In this case, it is better to use herbicides or to mechanically remove the hydrilla before stocking the fish, or better yet, wait for cooler water temperatures before stocking. A few measurements of dissolved oxygen made just prior to sunrise, particularly during the summer, will give a good indication of whether sufficient dissolved oxygen is present for good fish survival. Dissolved oxygen readings of at least $3 \mathrm{ppm}$ will help ensure good survival of the fish. It should also be noted that dissolved oxygen levels tend to decrease with increasing water temperature.

Use of herbicides to remove a majority of the biomass of hydrilla before stocking with grass carp will reduce the number of fish required, since the fish need to consume only the newly emerging hydrilla growth. This integrated approach appears to be an efficient and cost-effective way to manage hydrilla.

When herbicides are used, sufficient time must be allowed for the indirect effects of the herbicide to diminish prior to stocking grass carp. Although most aquatic herbicides are not toxic to fish, the decaying vegetation may reduce dissolved oxygen to levels unsuitable for good survival of fish. Oxygen measurements should be taken to indicate whether the water is suitable for stocking grass carp.

In small bodies of water, 5 fish per acre (13 grass carp per hectare) have controlled hydrilla regrowth following use of herbicides. Rates lower than this may be possible since 5 fish per acre in some situations will eliminate all submersed plant growth. Therefore, to prevent regrowth of hydrilla but at the same time allow for growth of other desirable plants, rates of 1 to 3 fish per acre ( 3 to 8 fish per hectare) may be suitable, with an occasional spot treatment of herbicide to control any new growth of hydrilla which becomes more abundant than the fish can consume.

One area of interest is the use of grass carp to manage hydrilla concomitant with establishment of desirable, native aquatic plants. In order to accomplish this, low numbers of fish or the use of plants low on the list of foods preferred by the fish are important considerations. With grass carp it may be possible to eliminate hydrilla in many bodies of water and promote growth of desirable aquatic plants to enhance water quality.

The grass carp has also provided control of hydrilla in some flowing water situations. Figure 5 and Figure 6 show an agricultural canal before and after use of herbicides and stocking of grass carp.

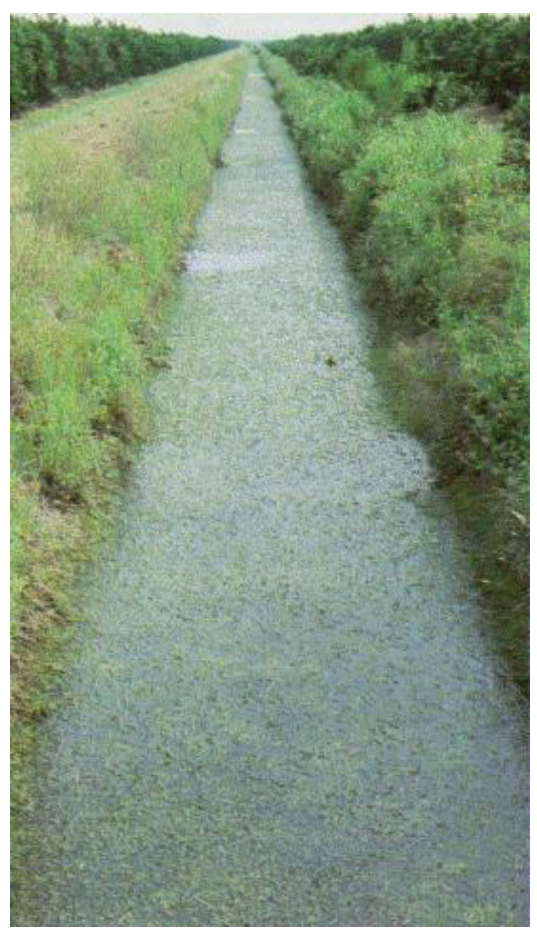

Figure 5. Southwest Florida citrus irrigation and drainage ditch with dense Hydrilla which blocks water movement.

Credits: David L. Sutton

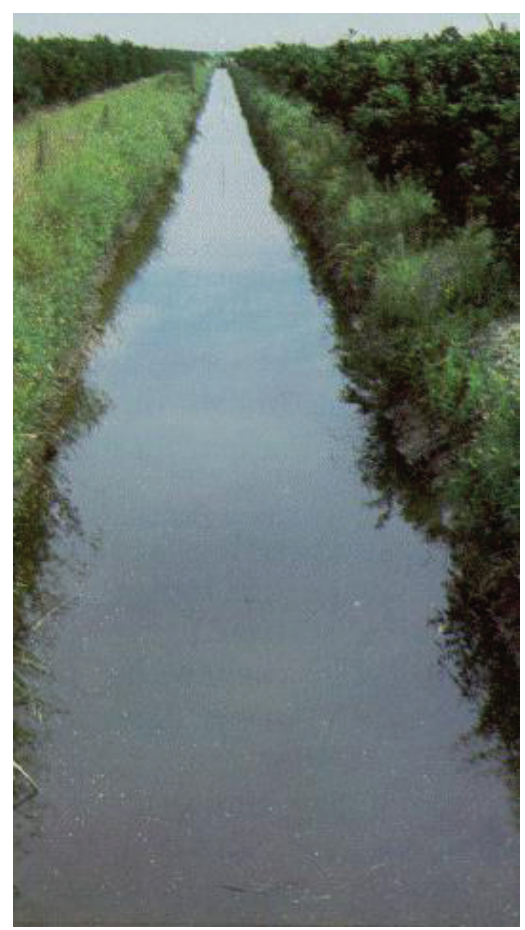

Figure 6. Southwest Florida citrus irrigation and drainage ditch with Hydrilla controlled by grass carp following herbicide application. Twenty fish per acre can manage Hydrilla and shoreline grasses under these conditions and give economical long-term control. Credits: David L. Sutton

Limited work has been done on the use of grass carp in conjunction with mechanical control methods prior to fish stocking. However, it is likely that the number of fish required following mechanical removal of hydrilla would be higher than the number required after application 
of herbicides, but considerably lower than the number required if fish alone were used.

Stocking of grass carp must take place after any negative effects of mechanical harvesting have diminished. For example, a temporary reduction in dissolved oxygen may occur during harvesting, due to sediment disturbance and suspension of decaying material in the water.

Mechanical methods can be especially useful for removing portions of dense mats of weeds. This creates weed-free refuge areas where the fish would not be subjected to the low oxygen levels that can occur in the thick mat of plants.

The time of year to stock grass carp depends primarily on availability of fish and on water quality. When the fish are used in conjunction with herbicides or mechanical methods, stocking needs to be done prior to regrowth of hydrilla but after the effects of these treatments have dissipated.

The fish can be transported and handled much easier during cooler months than during the hot summer months. Injured fish are less susceptible to diseases when stocked in cool water rather than warm water. Also, as discussed earlier, cool water contains more dissolved oxygen than warm water.

In bodies of water with culverts or canals leading to other areas, screens or gates must be installed to prevent escape of the grass carp. Barriers need to be constructed so the fish cannot jump over them. Screens (Figure 7) have proven effective in preventing movement of grass carp while allowing unrestricted movement of water. This type of barrier must have spaces between the bars narrower than the stocked grass carp's body width.

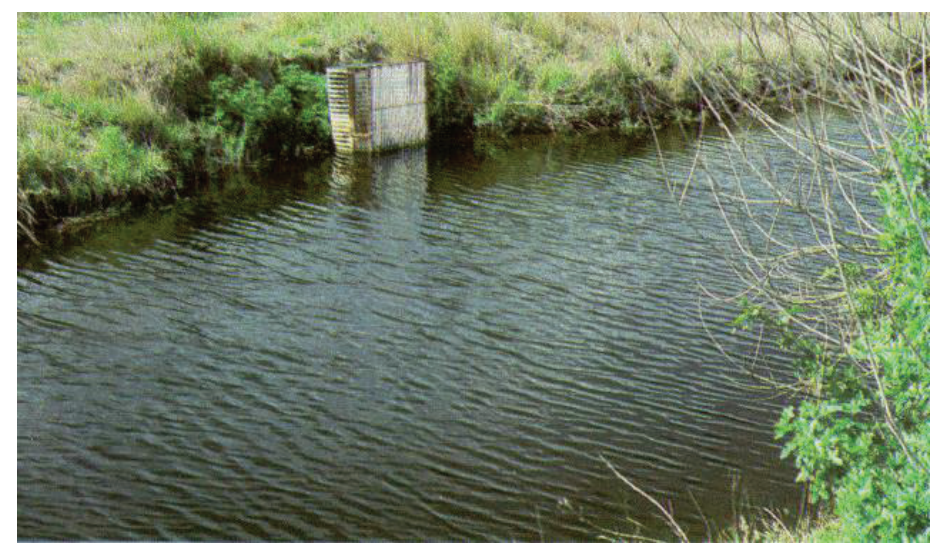

Figure 7. Fish barrier installed on a water control structure in a citrus irrigation and drainage canal. Fish barriers are used to manage unwanted grass carp movement in the agricultural waterways. Credits: David L. Sutton
Grass carp are extremely difficult to remove from a body of water. Draining the water or using a fish toxicant such as Rotenone are two ways to remove them.

\section{Permit Requirements for Grass Carp}

In Florida, a permit is required by law for use or possession of grass carp. Only grass carp certified as triploid can be used in an aquatic weed management program. Individuals interested in using grass carp for aquatic weed management may contact the University of Florida Institute of Food and Agricultural Sciences, Cooperative Extension Service or the Florida Fish and Wildlife Conservation Commission for assistance in stocking rates, suppliers of certified triploid grass carp, and procedures for obtaining a permit. Application for a permit may be obtained by contacting the Florida Fish and Wildlife Conservation Commission at the following website: https://public.myfwc.com/crossdoi/ triploidgrasscarp/default.aspx.

\section{Summary}

Management of hydrilla and other aquatic weeds in many bodies of water is possible with grass carp. An integrated management program consisting of low stocking rates of fish combined with applications of herbicides or mechanical control methods may be the best way to reduce nuisance growth of weeds. This approach may also encourage growth of desirable native aquatic plants. Converting unwanted weeds to valuable fish protein is an additional benefit of using grass carp.

\section{Additional Readings}

Cross, D. G. 1969. Aquatic weed control using grass carp. J. Fish Biol. 1:27-30.

Shireman, J. V. and C. R. Smith. 1983. Synopsis of Biological Data on the Grass Carp Ctenopharyngodon idella (Cuvier and Valenciennes, 1844). FAO Fisheries Synopsis No. 135. $86 \mathrm{pp}$.

Sutton, D. L. 1974. Utilization of hydrilla by the white amur. Hyacinth Contr. J. 12:66-70.

Sutton, D. L. 1977. Grass carp Ctenopharyngodon idella Val. in North America. Aquatic Botany 3:157-164.

Swingle, H. S. 1957. Control of pondweeds by use of herbivorous fishes. Proc. South. Weed Conf. 10:11-17. 
Van Dyke, J. M. and D. L. Sutton. 1977. Digestion of duckweed (Lemna spp.) by the grass carp Ctenopharyngodon idella. J. Fish Biol. 11:273-278.

Van Dyke, J. M., A. J. Leslie, Jr., and L. E. Nall. 1984. The effects of the grass carp on the aquatic macrophytes of four Florida lakes. J. Aquat. Plant Manage. 22:87-95.

\section{Acknowledgments}

The authors would like to thank W. B. Ennis, Jr., J. C. Joyce, C. L. Phillippy, J.V. Shireman, J. G. Stanley, J. M. Van Dyke, and F. J. Ware for their critical review of this article.

Table 1. Crass Carp Feeding Preferences

\begin{tabular}{|c|c|c|}
\hline $\begin{array}{l}\text { Order of } \\
\text { Preference }\end{array}$ & Common Name & Scientific Name \\
\hline 1 & Hydrilla & Hydrilla verticillata (L.f.) Royle \\
\hline 2 & Muskgrass & Chara spp. \\
\hline 3 & $\begin{array}{l}\text { Southern Waternymph; Southern } \\
\text { Naiad }\end{array}$ & Najas guadalupensis (Spreng.) Magnus \\
\hline 4 & $\begin{array}{l}\text { Brazilian Waterweed; Brazilian Egeria; } \\
\text { Brazilian Elodea }\end{array}$ & Egeria densa Planch. \\
\hline 5 & Watermeal & Wolffia spp. \\
\hline 6 & Duckweed & Lemna spp.; Spirodela spp.; Landoltia spp. \\
\hline 7 & Azolla; Waterfern; Mosquitofern & Azolla spp. \\
\hline 8 & Pondweeds & Potamogeton spp.; Stuckenia pectinata (L.) Börner; Zannichellia palustris L. \\
\hline 9 & Coontail & Ceratophyllum demersum L. \\
\hline 10 & Torpedograss & Panicum repens $\mathrm{L}$. \\
\hline 11 & Cattail & Typha spp. \\
\hline 12 & Crab's-claw; Wateraloe & Stratiotes aloides L \\
\hline 13 & Watercress & Nasturtium spp. \\
\hline 14 & Eurasian Watermilfoil & Myriophyllum spicatum L. \\
\hline 15 & Tapegrass; American Eelgrass & Vallisneria americana Michx. \\
\hline 16 & Parrotfeather & Myriophyllum aquaticum (Vell.) Verdc. \\
\hline 17 & Waterhyacinth & Eichhornia crassipes (Mart.) Solms \\
\hline 18 & Waterlettuce & Pistia stratiotes L. \\
\hline 19 & Waterlily & Nymphaea spp. \\
\hline 20 & Spatterdock & Nuphar lutea ssp. advena (Ait.) Kartesz \& Gandhi \\
\hline
\end{tabular}

